\title{
Radiocarbon
}

1968

\section{ANU RADIOCARBON DATE LIST II}

\section{H. A. POLACH, ${ }^{*}, *$ J. GOLSON, **}

J. F. LOVERING, * and J. J. STIPP*

Australian National University, Canberra, Australia

The $\mathrm{C}^{14}$ measurements reported here were carried out by the Radiocarbon Laboratory, Dept. of Geophysics and Geochemistry, A.N.U., between Jan. and Aug. 1967. Laboratory equipment consists of a Beckman methane gas-proportional unit (ANU I) supplemented in Dec. 1966 by an automatic 3-channel Beckman model LS-200 liquid scintillation spectrometer. Synthesis of methane and benzene is the same as used in ANU I and described by Polach and Stipp (1967). Treatment of samples remains a $2 \mathrm{~N}$ hot acid (HCl) wash unless otherwise specified. Where applicable, fractional separation follows procedures reported by Olson (1963), Berger et al. (1964), Tamers and Pearson (1965), and Krueger (1966). In the treatment of bone samples, physical or mechanical cleaning could not completely remove sedimentary material often filling the structural pores. This material, if present, was retained with the fraction referred to as "collagen". Since we are not dealing with pure collagen, we prefer to call it "acid-insoluble" bone fraction, a name describing the treatment. These dates are reported as equal to or greater than given age. Table 1 summarizes all dated fractions.

TABLE 1

Dated fractions of samples (ANU II)

\begin{tabular}{|c|c|c|}
\hline $\begin{array}{l}\text { ANU } \\
\text { Number }\end{array}$ & $\begin{array}{l}\text { ANU } \\
\text { Date }\end{array}$ & Fraction dated \\
\hline $\begin{array}{r}A N U-37 a \\
37 b\end{array}$ & $\begin{array}{r}910 \pm 110 \\
\geqslant 2420 \pm 110\end{array}$ & $\begin{array}{l}\text { bone carbonate } \\
\text { acid-insol. bone frac. }\end{array}$ \\
\hline $\begin{array}{r}\mathrm{ANU}-38 \mathrm{a} \\
38 \mathrm{~b}\end{array}$ & $\begin{array}{r}3470 \pm 60 \\
\geqslant 8230 \pm 190\end{array}$ & $\begin{array}{l}\text { bone carbonate } \\
\text { acid-insol. bone frac. }\end{array}$ \\
\hline $\begin{array}{r}A N U-41 a \\
41 b\end{array}$ & $\begin{array}{r}6750 \pm 100 \\
\geqslant 10,730 \pm 370\end{array}$ & $\begin{array}{l}\text { bone carbonate } \\
\text { acid-insol. bone frac. }\end{array}$ \\
\hline $\begin{array}{r}\mathrm{ANU}-46 \mathrm{a} \\
46 \mathrm{~b}\end{array}$ & $\begin{array}{c}\delta^{14} \mathrm{C}+47 \pm 5 \% \text { w.r.t } .95 \mathrm{NBS} \text { oxalic standard } \\
495 \pm 100\end{array}$ & $\begin{array}{l}\mathrm{NaOH} \text {-sol. ("humic") } \\
\mathrm{NaOH} \text {-insol. charcoal }\end{array}$ \\
\hline ANU-65a & Too small to date & $\mathrm{NaOH}$-sol. ("humic") \\
\hline $65 \mathrm{~b}$ & $\begin{array}{r}31,600+1100 \\
-1300\end{array}$ & $\mathrm{NaOH}$-insol. charcoal \\
\hline $\begin{array}{r}\text { ANU-77a } \\
77 \mathrm{~b}\end{array}$ & $\begin{array}{l}24,800 \pm 1600 \\
22,900 \pm 1000\end{array}$ & $\begin{array}{l}\text { NaOH-sol. ("humic") } \\
\text { NaOH-insol. charcoal }\end{array}$ \\
\hline ANU-81a & Too small to date & NaOH-sol. ("humic”) \\
\hline $81 \mathrm{~b}$ & $\begin{array}{r}24,000+3300 \\
-5700\end{array}$ & $\mathrm{NaOH}$-insol. charcoal \\
\hline
\end{tabular}

* Department of Geophysics and Geochemistry

** Department of Anthropology and Sociology 
The system of interlaboratory cross checks and independent duplicate measurements referred to in ANU I has been continued and results are summarized in Table 2.

TABLE 2

Interlaboratory cross checks and duplicate determinations

\begin{tabular}{|c|c|c|c|c|}
\hline $\begin{array}{l}\text { ANU } \\
\text { Number }\end{array}$ & $\begin{array}{l}\text { ANU } \\
\text { Date }\end{array}$ & $\begin{array}{l}\text { Other } \\
\text { Number }\end{array}$ & $\begin{array}{l}\text { Other } \\
\text { Date }\end{array}$ & References \\
\hline $\begin{array}{l}\text { ANU-23 } \\
\text { ANU-23/2 }\end{array}$ & $\begin{array}{l}330 \pm 100 \\
340 \pm 63\end{array}$ & & & $\begin{array}{l}\text { ANU I } \\
\text { ANU II }\end{array}$ \\
\hline $\begin{array}{l}\text { ANU-30/1 } \\
\text { ANU-30/2 }\end{array}$ & $\begin{array}{l}250 \pm 75 \\
274 \pm 70\end{array}$ & N-294 & $225 \pm 110$ & $\begin{array}{l}\text { ANU II } \\
\text { Bowler, pers. commun. }\end{array}$ \\
\hline $\begin{array}{l}\text { ANU-69 } \\
\text { ANU-69/2 }\end{array}$ & $>37,000$ & & & ANU II \\
\hline$* \mathrm{ANU}-70$ & $15,850 \pm 320$ & GaK-5̆10 & $13,700 \pm 270$ & $\begin{array}{l}\text { ANU II } \\
\text { Wright, pers. commun. }\end{array}$ \\
\hline $\begin{array}{l}\text { ANU-92/1 } \\
\text { ANU-92/2 }\end{array}$ & $\begin{array}{l}3015 \pm 140 \\
3100 \pm 85\end{array}$ & & & ANU II \\
\hline ANU-133 & $30,030 \pm 810$ & W-901 & $30,800 \pm 1000$ & $\begin{array}{l}\text { ANU II } \\
\text { USGS VI }\end{array}$ \\
\hline *ANU-180 & $21,200 \pm 700$ & V-92 & $19,900 \pm 2000$ & $\begin{array}{l}\text { ANU II } \\
\text { Wright, pers. commun. }\end{array}$ \\
\hline
\end{tabular}

* A recollection of samples previously submitted for dating. All others are independent determinations on identical samples.

Ages are relative to A.D. 1950, calculated on the basis of Libby halflife of $5568 \mathrm{yr}$. We have changed our practice of reporting the error. Since this is based, at 1 standard deviation, solely on statistical counting errors of the Background, Sample and Oxalic modern reference, we now propose to report it as such, instead of enlarging to $\pm 100 \mathrm{yr}$ minimum as previously. To allow for other sources of error in the dating process (Anderson and Levi, 1952; Tauber, 1958; Libby, 1963; Polach and Golson, 1966), particularly those reported at $2 \%$ or less and/or referring to the last few millennia (Stuiver and Suess, 1966; Stuiver, 1967; Suess, 1967) we recommend that readers double the errors quoted in this list. Ages less than $200 \mathrm{yr}$ should be considered modern. All ages in the following list were produced by liquid scintillation counting of benzene samples. One day is equivalent to 1300 min counting time. Benzene dilution means the sample did not produce enough benzene to fill the counting vial and "dead" benzene was introduced to make up the volume.

\section{ACKNOWLEDGMENTS}

Part of the work is supported by a grant from the Australian Inst. of Aboriginal Studies (A.I.A.S.); in this connection we acknowledge the help of D. J. Mulvaney, Dept. of Anthropol., A.N.U. M. Trotman, of the Electronics section of the Research School of Physical Sciences, A.N.U., has continued to give technical assistance. 
A.I.A.S.

Anthropology

A.N.U.

C.S.I.R.O.

Geography

Geophysics
ABBREVIATIONS

: Australian Institute of Aboriginal Studies, Canberra.

: Department of Anthropology and Sociology, Research School of Pacific Studies, A.N.U.

: Australian National University, Canberra

: Commonwealth Scientific and Industrial Research Organization, Canberra

: Department of Geography, Research School of Pacific Studies, A.N.U.

: Department of Geophysics and Geochemistry, Research School of Physical Sciences, A.N.U.

\section{SAMPLE DESCRIPTIONS}

I. GEOLOGIC SAMPLES

Australia

\section{Echuca series, Victoria}

Samples coll. during project on late Quaternary to Recent alluvial deposition on Riverine plain near Echuca, relating to sequence previously determined by Bowler and Harford (1966) in which late Quaternary neotectonic movement diverted major rivers in area and initiated complex sequence of lake, lunette, and fluviatile development.

\section{ANU-29. Goulburn river}

$13,500 \pm 700$

Charcoal from remains of fire in alluvial silts later buried by overbank deposition to depth 116 in. below present ground surface. Section exposed in left bank of Goulburn R. $9.5 \mathrm{mi}$ ENE of Echuca, $\left(36^{\circ} 5^{\prime} \mathrm{S}\right.$ Lat, $144^{\circ} 54^{\prime} \mathrm{E}$ Long). Channel geometry of streams which deposited silts (Coonamoidgal II, Pels, 1966) indicates higher discharges than in present hydrological regime. Coll. 1966 by J. M. Bowler and F. Chamalaun, A.N.U.; subm. by Geography. Benzene dilution, 1-day count. Comment (J.M.B.): with N-296, 13,400 \pm 340 (11,450 в.C.) (Hamada, pers. commun.) indicates streams older than previously estimated and correlative with late glacial phase.

\section{ANU-30. Campaspe prior stream}

\section{A.D. 1690}

$260 \pm 51$

Charcoal from narrow vertical concentration ( 1 in. $x 8$ in.) in stream bed gravels beneath 78 in. of younger sediments exposed in gravel pit $6.5 \mathrm{mi} \mathrm{NE}$ of Rochester, (36 $16^{\circ} \mathrm{S}$ Lat, $144^{\circ} 47^{\prime} \mathrm{E}$ Long). Sample, apparently truncated by cross-bedded gravels, first assumed from tree growing in situ while stream activity deposited bedload. Stream now inactive with mature red-brown earth soil profile developed on alluvium over gravels. Coll. 1966 by J. M. Bowler; subm. by Geography. Result is 
average of 2 independent determinations, both benzene, 1-day counts: ANU-30/1, $250 \pm 75$ and ANU-30/2, $274 \pm 70$. Comment (J.M.B.): date confirmed by N-294, $225 \pm 110$ (A.D. 1725) (Hamada, pers. commun.). Too young to permit soil profile development; sample must be regarded as intrusive.

ANU-69. Khancoban, New South Wales

Lignitized wood coll. $22 \mathrm{ft}$ below surface in fresh water alluvium of old creek meander beneath torrential gravel deposits derived from Khancoban Creek, alt $962 \mathrm{ft}\left(36^{\circ} 13^{\prime} \mathrm{S}\right.$ Lat, $148^{\circ} 7^{\prime} \mathrm{E}$ Long). Coll. 1963 by K. R. Sharp, Snowy Mts. Hydro-electric Authority; subm. by Geophysics. Benzene, 3-day count. Result at 95\% level of confidence. Another independent determination, ANU-69/2, benzene dilution, 1-day count, gave $>30,000$ B.P. Comment (K.R.S.): alluvium in area almost $250 \mathrm{ft}$ thick, highly weathered in lower parts. Upper $30 \mathrm{ft}$ contains evidence of geologically recent flood(s) bringing enormous amounts of debris and causing major stream derangement. Dates this as $>37,000$ B.P., though there may have been later events.

\section{ANU-76. Toolong Range, Upper Tumut Valley 33,250 в.c.}

Partly carbonized wood augered from depth $190 \mathrm{~cm}$ from quartz gravels beneath basalt blockstream, alt $5300 \mathrm{ft}\left(36^{\circ} 9^{\prime} \mathrm{S}\right.$ Lat, $148^{\circ} 22^{\prime}$ E Long). Blockstreams are regarded as periglacial phenomena, implying more rigorous climate than present. Sample provides terminus post quem for such climatic phase. Coll. 1967 by J. N. Jennings, A.N.U.; subm. by Geography. Benzene, 1-day count. Comment (J.N.J.): accords well with date of Costin's Munyang soil humus beneath solifluctional valley fill, NZ-596, 31,300 \pm 2300 (29,350 B.C.) (Costin, pers. commun.); valuable addition to meager chronology of Pleistocene and Recent climatic events in this part of Australia.

\section{Grove Creek series, Geary's Gap, New South Wales}

Charcoal and decomposed plant remains (some highly mineralized) from base of 3 terrace deposits of Grove Creek $\left(35^{\circ} 06^{\prime} \mathrm{S}\right.$ Lat, $149^{\circ} 22^{\prime}$ E Long), $23 \mathrm{mi} \mathrm{NE}$ of Canberra. Coll. 1967 by R. J. Coventry, A.N.U.; subm. by C.S.I.R.O.

ANU-91. $\quad K_{3}$ terrace

$6770 \pm 75$ 4820 B.. .

Decomposed twigs and/or charcoal, highly mineralized, from $\mathrm{K}_{3}$ terrace (well-differentiated yellow podzolic soil), overlain by $\mathrm{K}_{2}$ terrace (gray minimal prairie soil). Coll. from ca. $3 \mathrm{sq} \mathrm{ft,} 6$ in. back from exposed face. Benzene, 2-day count. Comment (R.J.C.): younger than expected. Walker (1962) reports $29,000 \pm 800$ (27,050 B.C.), NZ intralaboratory reference CR563, for similar terrace at Nowra, New South Wales. ANU91 agrees with 2 other dates from $\mathrm{K}_{3}$ terraces in NSW, V-13, $6425 \pm$ 130 B.P. (4475 B.c.) (Walker, pers. commun.) at Kempsey, and GrN-3119, 
$6250 \pm 90$ (4300 B.c.) (Costin, pers. commun.) at Berridale. Without further dates from different regions, only tentative age-correlations may be implied.

\section{ANU-92. $K_{2}$ terrace}

$\mathbf{3 0 6 5} \pm \mathbf{8 0}$

Decomposed twigs and/or charcoal of high ash content from base of $\mathrm{K}_{2}$ terrace (gray minimal prairie soil) above and $10 \mathrm{ft} \mathrm{N}$ of ANU-91. Result is weighted mean of 2 independent determinations. ANU-92/1, $3015 \pm 140$ (dilution) and ANU-92/2, $3100 \pm 85$, both benzene, 1-day counts.

\section{ANU-93. $K_{2}$ terrace}

$$
2460 \pm 75
$$

Charcoal fragments from base of exposed face of $\mathrm{K}_{2}$ terrace, $7 \mathrm{ft}$ below surface and $500 \mathrm{~m} \mathrm{NE}$ of ANU-91 and 92. Benzene, 1-day count.

\section{ANU-94. $K_{2}$ terrace}

$1775 \pm 85$

Charcoal fragments of high ash content from base of exposed face of $\mathrm{K}_{2}$ terrace, $6 \mathrm{ft}$ below surface and $1000 \mathrm{~m}$ NE of ANU-93. Benzene, 1-day count.

General Comment (R.J.C.): ANU-92 and 93 agree with ages for base of $\mathrm{K}_{2}$ terrace at Nowra, New South Wales, $3740 \pm 100$ (1790 B.C.), New Zealand intralaboratory reference CR564, (Walker, pers. commun.) and Kempsey, New South Wales, V-12A, $3225 \pm 140$ (1275 B.c.), and V-12B, $3300 \pm 100$ (1350 в.c.), (Walker, pers. commun.). Also with solifluction deposits at Mt. Kosciusko, New South Wales, ranging from Y-1096, 1540 \pm 160 (A.D. 410 ) to Y-1092, $2910 \pm 130$ (960 B.C.), (Yale VIII), attributed to colder conditions.

\section{ANU-95. $K_{1}$ terrace}

$255 \pm 64$

Charcoal fragments from base of $\mathrm{K}_{1}$ (regosol) with little or no pedological differentiation, ca. $5 \mathrm{ft}$ above ANU-94 and $1 \mathrm{ft}$ below surface. Coll. over wide area way from exposed face. Benzene, 1-day count. Comment (R.J.G.): ANU-95 may correlate with youngest solifluction deposits at Mt. Kosciusko dated at $170 \pm 100$ (Y-1090, Yale VIII) as well as with $390 \pm 60$ (A.D. 1560), New Zealand intralaboratory reference CR566, (Walker, pers. commun.) for $\mathrm{K}_{1}$ terrace at Nowra. Lack of pedological differentiation implies last phase of landscape instability of region was initiated prior to arrival of Europeans.

General Comment (R.J.C.): above samples represent 1st series for Kcycle (Butler, 1959) deposits on S. Tablelands; results consistent with terrace stratigraphy.

\section{VEGETATION HISTORY}

New Guinea

\section{Lake Birip series, Wabag Subdistrict, Western Highlands District}

Swamp at edge of crater lake, alt $6200 \mathrm{ft}\left(50^{\circ} 34^{\prime} \mathrm{S}\right.$ Lat, $143^{\circ} 50^{\prime} \mathrm{E}$ 
Long) worked by J. R. Flenley, A.N.U., during vegetation history project. All samples coll. with peat borer 1964 by J. R. Flenley; subm. by Geography.

ANU-63. A14, 67 to $72 \mathrm{~cm}$ deep

$2930 \pm 140$

Soft brown coarse detritus mud with gray silt believed to be volcanic ash. Benzene dilution, 1-day count.

$275 \pm 70$

ANU-64. A14, 72 to $77 \mathrm{~cm}$ deep

A.D. 1675

Same as ANU-63.

$305 \pm 90$

ANU-79. A14, 62 to $67 \mathrm{~cm}$ deep

A.D. 1645

Soft brown coarse detritus mud. Benzene dilution, 2-day count.

ANU-80. A14, 77 to $82 \mathrm{~cm}$ deep

$140 \pm 70$

Same as ANU-79.

General Comment (J.R.F.): ANU-63 and 64 subm. to date sharp decline in forest pollen and complementary rise in pollen of Casuarina. ANU79 and 80 subm. when ANU-63 gave discordant result. ANU-63, 64, and 80 might indicate stratigraphic inversion. However, ANU-64 and 80 do not differ significantly. ANU-63 is older than samples taken over depths from 215 to $285 \mathrm{~cm}$ in same sequence and dated between $1520 \pm 100$ (A.D. 430 ) and $2440 \pm 90$ (490 B.C.), (GaK-825 to 828 and GaK-665 to 667, Gakushuin VI). Perhaps ANU-63 contains material dug out during construction of pools for cultivation of Eleocharis elegans Willd., such construction stratigraphically postdating ANU-80. Casuarina sp. planted on dry ground around lake but also occurs naturally along watercourses. Rise in Casuarina pollen, dated by samples, may be important in interpreting effects of human disturbance of vegetation around lake.

\section{ARCHAEOLOGIC SAMPLES}

\section{A. Australia}

\section{Graman Area B series, New England, New South Wales}

Samples from 2 rock shelter sites, Site $1\left(29^{\circ} 24^{\prime} \mathrm{S}\right.$ Lat, $150^{\circ} 44^{\prime} \mathrm{E}$ Long) and Site $4\left(29^{\circ} 25^{\prime} \mathrm{S}\right.$ Lat, $150^{\circ} 46^{\prime} \mathrm{E}$ Long), on Girrawheen Sta., $8 \mathrm{mi}$ NW of Graman, excavated by Isabel McBryde, Univ. of New England, as part of long-term project on archaeology of $\mathbf{N}$ New South Wales (McBryde, 1962). Coll. 1966 by I. McBryde; subm. by A.I.A.S.

ANU-54. Site 1, Trench 2, Zone (d), $2760 \pm 65$ Level II, Spit 1

Scattered charcoal from $\mathrm{N}$ end of trench, 16 to 19 in. below surface of deposit, upper part of Level II. Associated with industry of backed 
blades. Charcoal from Spit 2, Level II in same area of trench (Zone (d)), 19 to 28 in. below surface, is dated by GaK-1188, $3950 \pm 50$ (2000 B.c.) (McBryde, pers. commun.). Level I, Zone (d), at depth 10 to 13 in. below surface dated by GaK-1187, $2040 \pm 70$ (90 B.c.) (McBryde, pers. commun.). Dates for levels in Trench 1, on parallel alignment 72 in. away, are Level I, 4 to 5 in. below surface, GaK-805, $4640 \pm 100$ (2690 B.c.) and for Level II, 18 in. below surface, GaK-806, $5450 \pm 100$ (3500 B.c.), (Gakushuin VI). Benzene, 1-day count. Comment (I. McB.): dates from A.N.U. and Gakushuin for samples from Zone (d), Trench 2 are consistent but more recent than 2 dates from stratigraphic levels of Trench I (GaK-805 to 806).

\section{ANU-55. Site 4, Trench 1, Zone (a), Level I}

$$
2050 \pm 55
$$$$
100 \text { B.C. }
$$

Sample from concentration of charcoal 6.5 in. below surface of deposit at base of Level I, associated with industry of backed blades, also bone artifacts. Another date for Level I, Zone (c) Trench 1, ca. 72 in. away and 13 in. below surface, is GaK-1189, $1750 \pm 80$ (A.D. 200), (McBryde, pers. commun.). Benzene, 1-day count. Comment (I. McB.): ANU-55 agrees with GaK-1189. Though closer to surface, ANU-55 was at base of Level I, whereas GaK-1189 was higher in that level.

ANU-56. Site 4, Trench 1, Zone (b), Level II

$$
2290 \pm 62
$$

$$
340 \text { B.c. }
$$

Concentration of charcoal 18.5 in. below surface of deposit in lower part of Level II, associated with rich collection of bone and stone implements (including backed blades). Another date for Level II, 60 in. away in Zone (d), 13 in. below surface, is GaK-1190, $2480 \pm 80 \quad(530$ B.c.), (McBryde, pers. commun.). Benzene, 1-day count. Comment (I.McB.): ANU-56 and GaK-1190 agree.

General Comment (I. McB.): samples provide additional data on chronology of backed blade industries in E New South Wales, early dates for these industries at Site 1 being of particular interest. For details of backed blade chronology see introduction to Lapstone Creek series in A.N.U. I.

\section{Oenpelli series, Northern Territory}

Samples coll. during 2nd season of archaeological project during which 5 rock shelters in vicinity of Oenpelli mission were excavated, 2 (Tyimede 1 and 2) in Arnhem Land escarpment, 3 (Malangangerr, Nawamoyn, and Padypadiy) in sandstone residuals on alluvial plains of East Alligator R. Besides differences of ecological adaptation in plain and plateau sites, excavation documented technological change in region as a whole. Later industry occurs at all sites, characterized by stone points and edge-ground axes. Early industry occurs at Malangangerr, Nawamoyn, and Tyimede 2, characterized by chunky scrapers and edge-ground axes (C. White, 1967) (cf. Ingaladdi series, ANU-57, 58, and 60). 
Dates previously available are

Later industry

Malangangerr, upper level GaK-626 $\quad 370 \pm 80 \quad$ (A.D. 1580)

(Gakushuin V)

Malangangerr, lower level

GaK-627 $5980 \pm 140 \quad$ (4030 в.c.)

(Gakushuin V)

Padypadiy, lower level

(ANU I)

Tyimede 1, upper level

(Gakushuin V)

Tyimede 1, middle level

(Gakushuin V)

Tyimede 1, lower level

(Gakushuin V)

$$
\text { ANU-17 } 3120 \pm 100 \quad \text { (1170 B.C.) }
$$

GaK-630 <230 (Modern)

$\begin{array}{llll}\text { GaK-631 } & 1900 \pm 90 \quad \text { (A.D. 50) }\end{array}$

GaK-632 $10,790 \pm 200 \quad$ (8840 в.c.)

Earlier industry

Malangangerr

(Gakushuin V)

Malangangerr

(Gakushuin V)

Malangangerr

(ANU I)

Tyimede 2, presumably

later stage (ANU-1)

GaK-628 $19,600 \pm 550 \quad$ (17,650 B.c.)

GaK-629 $22,700 \pm 700 \quad$ (20,750 в.c.)

ANU-19 $18,000 \pm 400 \quad$ (16,050 в.c.)

ANU-18 $6650 \pm 500 \quad$ (4700 в.C.)

Two problems were presented by these dates: (1) age of GaK-632 from Tyimede 1 compared with other dates for later industry and final stage of earlier industry. ANU-52 from Tyimede 1 and ANU-50 from neighboring site of Tyimede 2 subm. to investigates this problem. ANU53 also relevant here; (2) unexpectedly but consistently old dates (GaK628 to 629 , ANU-19) for edge-ground axes. ANU-51 contributes to this question at another site. ANU-77a and 77b are lab's investigation of possibility of sample contamination at original site.

All samples coll. 1965 by Carmel White, A.N.U.; subm. by A.I.A.S.

\section{ANU-50. Tyimede 2}

$4770 \pm 150$

Charcoal from hearths? in sand at 29 to $34 \mathrm{~cm}$ depth dating earliest phase of later stone point industry at site $\left(12^{\circ} 26^{\prime} \mathrm{S}\right.$ Lat, $133^{\circ} 15^{\prime} \mathrm{E}$ Long). Benzene, 1-day count.

\section{ANU-51. Nawamoyn, Cannon Hill station}

$21,450 \pm 380$

Charcoal ca. $80 \mathrm{~cm}$ deep, in upper levels of sand below shell midden containing ANU-53. Dates earlier scraper and edge-ground axe industry at site (12 $23^{\prime} \mathrm{S}$ Lat, $132^{\circ} 56^{\prime} \mathrm{E}$ Long). Benzene, 1-day count. Comment (H.A.P.): originally reported 21,450 \pm 600 (C. White, 1967). 
ANU-52. Tyimede 1

$3820 \pm 100$

Charcoal 50 to $55 \mathrm{~cm}$ deep at same general level as GaK-632 in adjacent square. Dates earliest phase of stone point industry at site $\left(12^{\circ}\right.$ $24^{\prime}$ S Lat, $133^{\circ} 15^{\prime}$ E Long). Benzene, 1-day count.

\section{ANU-53. Nawamoyn, Cannon Hill station}

$7110 \pm 130$

Charcoal 42 to $48 \mathrm{~cm}$ deep, in base of shell midden above sand containing ANU-51. Dates early phase of stone point industry at site (12 ${ }^{\circ} 23^{\prime} \mathrm{S}$ Lat, $132^{\circ} 56^{\prime} \mathrm{E}$ Long). Benzene dilution, 1-day count. Comment (H.A.P.): originally reported $7110 \pm 160$ (C. White, 1967).

ANU-77b. Malangangerr

$22,900 \pm 1000$

Charcoal in sand at 134 to $144 \mathrm{~cm}$ depth, $30 \mathrm{~cm}$ directly below ANU-19, dating early scraper and edge-ground axe industry at site $\left(12^{\circ}\right.$ $27^{\prime} \mathrm{S}$ Lat, $132^{\circ} 57^{\prime} \mathrm{E}$ Long). Age based on $\mathrm{NaOH}$-insoluble fraction, benzene dilution, 2-day count. ANU-77a, NaOH-soluble fraction, benzene dilution, 1-day count, dated 24,800 \pm 1600 (22,850 в.C.) Comment (H.A.P.): lack of significant difference between the 2 determinations indicates no intrusive carbon, young or old, in site.

General Comment (C.W.): ANU-51 and 77b confirm high antiquity of ground stone tools in Australia, suggested by GaK-628 to 629 and ANU19. Dates now available for early phase of stone point industry, ANU. 53 and GaK-627 on plains, and ANU-50 and 52 on plateau, suggest early date GaK-632 refers not to stone points but to pre-point phase which cannot be recognized through artifacts. ANU-18 would then fall into place as dating late stage of earlier industry on plateau (cf. C. White, 1967.)

\section{Ingaladdi rockshelter series, Willeroo station, Northern Territory}

Excavations at sandstone rockshelter ( $15^{\circ} 11^{\prime} \mathrm{S}$ Lat, $131^{\circ} 24^{\prime} \mathrm{E}$ Long) begun in 1963 by D. J. Mulvaney, then of Univ. of Melbourne. Occupation extends over depth $2 \mathrm{~m}$ and comprises upper industry of stone points, adze flakes, and edge-ground axes in sandy deposit in top 90 $\mathrm{cm}$, overlying core and flake tool industry in stony deposit in bottom $110 \mathrm{~cm}$. GX-103 dates later industry 37 to $48 \mathrm{~cm}$ below surface at $1545 \pm 75$ (A.D. 405); GX-104 dates earlier industry 85 to $98 \mathrm{~cm}$ below surface at $6255 \pm 135$ (4305 в.c.), (Geochron I). Renewed work in trench at $90^{\circ}$ to 1963 trench produced samples that follow, coll. 1966 by D. J. Mulvaney, A.N.U.; subm. by A.I.A.S.

\section{ANU-57. 84 to $90 \mathrm{~cm}$ below surface}

$$
2890 \pm 73
$$

Charcoal from base of sandy layer and beginning of later industry at site. Benzene, 1-day count. Comment (D.J.M.): GX-103 is relatively higher than ANU-57, which dates appearance of points and adze flakes at site. 


\section{ANU.58. 109 to $116 \mathrm{~cm}$ below surface}

Charcoal ca. $23 \mathrm{~cm}$ below ANU-57 towards top of stony accumulation and its contained core and flake tool industry. Benzene, 1-day count. Comment (D.J.M.): GX-104 stratigraphically lower in 1963 trench than ANU-58 in 1966 trench. Between ANU-58 and 57 important changes, both depositional (stony to sandy) and technological (core and flake tools to points and adze flakes), took place at site.

\section{ANU-60. 168 to $175 \mathrm{~cm}$ below surface}

$6800 \pm 270$

Charcoal towards base of stony accumulation. Benzene dilution, 1day count. Comment (D.J.M.): relatively lower in deposit than GX-104, it represents early stage of core and flake tool industry at site.

General Comment (D.J.M.): highly satisfactory agreement between all radiocarbon dates. 1966 excavations produced engraved art on rocks in rubbly layer, associated with core and flake tool industry.

\section{$125 \pm 57$}

ANU-61. Anuru Bay, Arnhem Land, Northern Territory Modern

Ash and charcoal ca. $25 \mathrm{~cm}$ below surface in stone fireplace on coastal beach $\left(11^{\circ} 45^{\prime} \mathrm{S}\right.$ Lat, $133^{\circ} 21^{\prime} \mathrm{E}$ Long). Lines of stone fireplaces, remains of smokehouses, and abundant pottery mark preparation campsites of Macassan trepangers. Activities historically dated from mid-18th to early 20th century and confirmed by Aboriginal tradition. Coll. 1966 by C. C. Macknight, A.N.U.; subm. by Anthropology. Benzene, 1-day count. Comment (C.C.M.): accords with historical dating of Macassan activity.

\section{ANU-62. Port Essington, Coburg Peninsula,} Northern Territory

$\mathbf{5 5 0} \pm \mathbf{5 7}$

A.D. 1400

Charcoal from 45 to $50 \mathrm{~cm}$ deep in Aboriginal shell midden $55 \mathrm{~cm}$ depth, adjacent to English military settlement (1 $11^{\circ} 22^{\prime} \mathrm{S}$ Lat, $132^{\circ} 9^{\prime}$ E Long) established 1838 and abandoned 1849 (Allen, 1967). European material occurs top 10 to $15 \mathrm{~cm}$ of midden. Coll. 1966 by F. J. Allen, A.N.U.; subm. by A.I.A.S. Benzene, 1-day count. Comment (F.J.A.): confirms conclusion reached on archaeological grounds that site occupied before settlement of Europeans and substantiates hypothesis that its function altered with that settlement.

\section{Keilor series, near Melbourne, Victoria}

Keilor terrace of Maribyrnong R. in vicinity of Keilor township has produced important information, especially skeletal, on late Pleistocene and early post-Pleistocene Aboriginal occupation of Australia (Gill, 1966; Bowler et al., 1967). Gill reports $18,000 \pm 500$ (16,050 в.C.), (NZ-207, New Zealand I-V), for lower part of terrace, on charcoal from what he has interpreted as small Aboriginal midden (bones of food animals, no stone work). 
Recent excavations in area (37 $52^{\prime} \mathrm{S}$ Lat, $144^{\circ} 50^{\prime} \mathrm{E}$ Long) into alluvial clays beneath Keilor terrace by A. Gallus and Victorian Archaeol. Soc., with discovery of strata (1a, 1, 2, 3) of broken bones (including extinct marsupials) and some stone, assumed result of Aboriginal occupation. Samples coll. 1965 (ANU-81) and 1966 (ANU-65) by A. Gallus; subm. by A.I.A.S.

\section{ANU-65. Trench 2, Stratum 2}

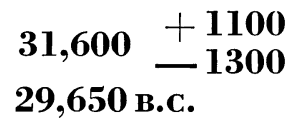

Charcoal from 3rd of 4 strata ca. 40 in. beneath base of Keilor terrace. Age based on $\mathrm{NaOH}$-insoluble fraction, benzene dilution, 2-day count. NaOH-soluble fraction too small for dating.

\section{ANU-81. Trench 2, beneath Stratum 2}

$$
24,000+\mathbf{3 3 0 0}
$$

Charcoal ca. 40 in. from ANU-65, where, due to recent river erosion, present surface is only ca. 4 in. above sample. Two isolated occurrences combined to make 1 sample: i) 2 in. below deepest level of Stratum 2; ii) at same level as and ca. 36 in. from Stratum 3, 6 to 7 in. lower than Stratum 2. Age based on NaOH-insoluble fraction, benzene dilution, 2day count. Sample yielded only 1/10th of full requirement, hence large errors. $\mathrm{NaOH}$-soluble fraction too small for dating.

General Comment (A.G.): ANU-65, if interpretation is upheld, significantly extends chronology of Aboriginal occupation of Australia, since it would be earliest date yet recorded. Also important for history of pre-Keilor Arundel terrace formations. Overlapping occurs at 2 standard deviations between ANU-65 and ANU-81, considered, on stratigraphic grounds, to be earlier. Alternatively ANU-81 may in part be younger carbon that has moved down through clays which are notoriously liquid when wet. High antiquity of formation confirmed.

\section{Koonalda cave series, Nullarbor Plain, South Australia}

Koonalda cave ( $31^{\circ} 25^{\prime} \mathrm{S}$ Lat, $129^{\circ} 53^{\prime} \mathrm{E}$ Long) is extensive system in limestone, ca. $225 \mathrm{ft}$ underground, entered by collapsed doline. Bands of chert in walls provided raw material for stone tool manufacture. Two trenches excavated by A. Gallus in 1956 and 1963: Trench III $450 \mathrm{ft}$ from entrance in dim light, Trench I $42 \mathrm{ft}$ further on in darkness. Trench III revealed undisturbed sequence of hearths in limestone rubble, one of which at depth ca. 24 in. was dated GaK-510, 13,700 $\pm 270(11,750$ B.c.) (Gallus, pers. commun.). In Trench I loose charcoal in limestone rubble at depth ca. 80 in. dated GaK-511 at 18,200 \pm 550 (16,250 в.c.), (Gallus, pers. commun.). Renewed excavation by Gallus in 1966 provided ANU-66 from Trench I and in 1967 ANU-180 from "Squeeze" area $460 \mathrm{ft}$ further into cave system.

Further work was organized for early 1967 by Koonalda Project Committee of Australian Inst. of Aboriginal Studies under direction of R. V. S. Wright, Univ. of Sydney, for whom ANU-70 and 71 were dated 
while in field, because of problem posed by ANU-66. ANU-148 and 149 are samples from Wright's excavation beneath limestone rubble from which all other dates derive, into water-lain, laminated red gravels, silts, and clays, 10 to $14 \mathrm{ft}$ thick at point of excavation and underlain by white limestone rubble. Red deposits, which were washed into cave, contain some artifacts and rich Pleistocene fauna. Ca. $4 \mathrm{ft}$ below their surface there is stratigraphic disconformity, ANU-148 being below, ANU-149 above this.

ANU-66. Trench I, ca. 170 to 185 in. deep

$$
\begin{aligned}
& 9400 \pm 1500 \\
& 7450 \text { в.c. }
\end{aligned}
$$

Charred twigs in limestone rubble 91 to 103 in. below level of GaK511. Coll. 1966 by A. Gallus; subm. by A.I.A.S. Benzene dilution, 1-day count. Comment (A.G.): stratigraphic inversion of ANU-66 and GaK511 might be explained by intrusion of younger charcoal down cracks between rubble before they were filled with limestone dust (ANU-66) or by similar intrusion of older charcoal from rock fall in cave (GaK-511).

ANU-70. Trench III, Area C, ca. 24 in. deep

$15,850 \pm 320$

Charred twigs from same zone of charcoal hearth(s)? as GaK-510. Coll. 1967 by R. V. S. Wright; subm. by A.I.A.S. Benzene, 1-day count. Comment (R.V.S.W.): significantly older than GaK-510 from same hearth, $13,700 \pm 270$ (11,750 B.C.), but general antiquity of level substantiated.

ANU-71. Trench III, Area C, ca. 60 in. deep

$19,300 \pm 350$

Charcoal from hearth 36 in. below ANU-70. Coll. 1967 by R. V. S. Wright; subm. by A.I.A.S. Benzene, 1-day count.

ANU-149. Trench III, Area C, ca. 108 in. deep $>10,000$

Charcoal of high ash content apparently from single burnt stick washed into place and found in silt-clay band in red deposits, without evidence of hearth or surrounding charcoal. Since silt-clay band is part of graded sequence of 75 to 100 sequential bands and charcoal is scarce, any charcoal incorporated within them could date their deposition fairly closely. Sample 30 in. below top of red deposits and 15 in. above disconformity within them. Coll. 1967 by R. V. S. Wright; subm. by A.I.A.S. Benzene dilution, 4-day count. Comment (H.A.P.): count rate 1.8 sigmas above background. Result calculated by Callow's formula (NPL III) for minimum age. Count rate based on $0.13 \mathrm{~g}$ benzene which is $1 / 27$ th of full requirement.

\section{ANU-148. Trench III, Area B, ca. 220 to 225} in. deep

Charcoal from notable concentration in single band of silt in deep red deposits with rare charcoal. Though sample was doubtless washed into cave, circumstances described for ANU-149 suggest relation to event 
shortly before deposition. Sample is ca. 160 in. below level of ANU-71 and $10 \mathrm{ft} \mathrm{S}$ of it and ca. $3 \mathrm{ft}$ from unexposed wall of cave at this level. It also lies ca. 95 in. below disconformity in red deposits, 1 to $2 \mathrm{ft}$ above underlying limestone rubble and $2 \mathrm{ft}$ below lowest pieces of flint acceptable as artifacts. Coll. 1967 by R. V. S. Wright; subm. by A.I.A.S. Benzene dilution, 1.5-days count.

General Comment (R.V.S.W.): GaK and ANU sequence of dates forms consistent depositional series where, because of random roof falls, depth is no measure of depositional rates. ANU-148 for bottom of excavation under graded red gravels and silts, although younger than expected, is acceptable as graded beds possibly accumulated in relatively short period, perhaps 300 yr (Jennings and Frank, A.N.U., pers. commun.).

ANU-180. Area 5, ca. 8 in. deep

$21,200 \pm 700$

Two combined samples of fragmented charcoal of high ash content from excavation at chert mining site in "Squeeze" area located in total darkness $850 \mathrm{ft}$ from cave entrance. Scattered roof fall rests on ca. 3 in. surface layer of dust covering rock and dust infilling of unknown depth, in which sample lay at ca. 5 to 8 in. below top of surface dust. Coll. 1967 by A. rallus; subm. by A.I.A.S. Benzene dilution, 2-day count. Comment (A.j.): Wright (pers. commun.) reports V-92, 19,900 \pm 2000 (17,950 B.c.), for sample coll. 1966 in same area. Both samples confirm antiquity of human activity within Koonalda cave system and near surface of its deposits.

\section{B. New Guinea}

\section{Batari cave series, Tairora Census Division, Eastern Highlands District}

Site in calcarenite in Lamari R. valley $5 \mathrm{mi} \mathrm{S}$ of Obura Patrol Post, alt $4200 \mathrm{ft}\left(6^{\circ} 36^{\prime} \mathrm{S}\right.$ Lat, $145^{\circ} 56^{\prime} \mathrm{E}$ Long). Excavations $1.6 \mathrm{~m}$ deep produced evidence similar to that of Aibura cave $13 \mathrm{mi} \mathrm{N}$ in same valley. Aibura is dated GaK-623, $3800 \pm 110$ (1850 B.c.) to later than GaK-622, $770 \pm 100$ (A.D. 1180) (Gakushuin V). At Batari flaked stone tool industry essentially homogeneous and hunting environment apparently stable throughout occupation (White, 1965 and 1967). Circumstances questioned validity of ANU-40 dating lowest cultural material; therefore ANU-38 from same horizon was dated. Samples coll. 1965 by J. P. White, A.N.U.; subm. by Anthropology.

\section{ANU-38b. Horizon IV}

$$
\begin{aligned}
& \geqslant 8230 \pm 190 \\
& 6280 \text { B. C. }
\end{aligned}
$$

Unidentifiable bones of food animals from lowest horizon in deposit at 70 to $100 \mathrm{~cm}$ depth. Age based on acid-insoluble bone fraction, benzene dilution, 2-day count. ANU-38a, bone carbonate, benzene, 2-day count, dated $3470 \pm 60$ (1520 B.c.). Comment (J.P.W.): ANU-38b probably dates earliest occupation at Batari (see ANU-40). 


$$
\mathbf{8 5 0} \pm \mathbf{5 3}
$$

ANU-39. Horizon I

A.D. 1100

Charcoal from lower part of large hearth forming topmost undisturbed level of occupation. Provides last date for all archaeological material at site and correlates with only domesticated animal bones found. Benzene, 1-day count. Comment (J.P.W.): upper horizon of flaked tools just below this date shows no evidence of technological change found at Aibura from 800 B.P.

\section{ANU-40. Horizon IV}

Scattered charcoal found in soil with artifacts below ANU-38; only carbon beneath ANU-39. Benzene dilution, 1-day count. Comment (J.P.W.): since sample only $20 \mathrm{~cm}$ laterally from culturally sterile riverine deposit containing spicules of carbon, date may not refer to human occupation. If carbon comes from natural sources, date documents 25 $\mathrm{m}$ of riverine downcutting since this time.

\section{Kafiavana rockshelter series, S Asaro valley, \\ Eastern Highlands District}

Site ( $6^{\circ} 14^{\prime} \mathrm{S}$ Lat, $145^{\circ} 25^{\prime} \mathrm{E}$ Long) described in ANU I. Striking feature is ground stone tools by 9500 B.P. (ANU-20, ANU I). Samples coll. 1965 by J. P. White; subm. by Anthropology.

\section{ANU-41b. 260 to $310 \mathrm{~cm}$ below surface}

$\geqslant 10,730 \pm 370$ 8780 B.c.

Unidentifiable bones of food animals associated with ground stone tool fragments and marine shells. Sample, from area of $6 \mathrm{~m}^{2}$ over depth $50 \mathrm{~cm}$, subm. to confirm ANU-20, immediately above. Age based on acid-insoluble bone fraction, benzene dilution, 2-day count. ANU-41a, bone carbonate, benzene, 1-day count, dated $6750 \pm 100$ (4800 B.c.). Comment (J.P.W.): ANU-41b in stratigraphically consistent series of 3 with ANU-20, not less than 9500 B.P. (ANU I), and New Zealand intralaboratory reference R1894B, $9290 \pm 140$ (7340 B.C.), (Rafter, pers. commun.). All confirm antiquity of ground stone axe/adzes (White, 1967).

$$
4690 \pm 170
$$

\section{ANU.42. Base of Horizon II, $50 \mathrm{~cm}$ below surface 2740 в.C.}

Charcoal from creamy white matrix of hearth?, just above upper of 2 main concentrations of artifacts. Benzene dilution, 2-day count. Comment (J.P.W.): sample comes from phase of high humus content, when site probably largely abandoned. Above it utilized flakes become common. Pig first appears below (cf. Bulmer, 1966). Date provides terminus ante quem for main occupation of Kafiavana.

\section{Manton plantation series, Mt. Hagen, Western Highlands District}

Site is superimposed series of former agricultural systems marked by digging of water-control ditches on alluvial flats of Wahgi R., $6 \mathrm{mi} \mathrm{E}$ of Mt. Hagen township, alt ca. $5200 \mathrm{ft}\left(5^{\circ} 51^{\prime} \mathrm{S}\right.$ Lat, $144^{\circ} 19^{\prime} \mathrm{E}$ Long). 
Rescue excavations conducted 1966 by R. J. Lampert, W. R. Ambrose, and J. Golson, and palynological investigations carried out by Jocelyn M. Wheeler, all A.N.U. Coll. 1966 by R. J. Lampert and W. R. Ambrose; subm. by Anthropology.

ANU-43. Trench M, Zone II

$2300 \pm 120$

Waterlogged wood from long pointed digging stick found in earliest of 3 superimposed drainage channels in zone of disturbed peat of prehistoric horticultural activity. Benzene dilution, 1-day count.

ANU.44. Trench N, Zone III

$4560 \pm 72$

Waterlogged wood from branch in thin zone of undisturbed peat immediately above basal clay and below zone of disturbed peat with drainage channels. Benzene, 1-day count.

General Comment (R.J.L.): pattern of ditches, agricultural implements, and stone tools dated by ANU-43 identical with those associated with dry-land sweet potato agriculture in modern times (Lampert, 1967). Date is well before introduction of sweet potato to New Guinea; lst direct dating of horticulture there (Golson et al., 1967).

\section{Watom Island series, New Britain, Bismarck Archipelago}

Pottery from Rakival village on island's NE coast $\left(4^{\circ} 5^{\prime} \mathrm{S}\right.$ Lat, $152^{\circ}$ 5' E Long), reported 1909 (Meyer) and 1936 (Casey), now attributed to early and widespread tradition in SW Pacific, called Lapita (Golson, 1961; Poulsen, 1964; Solheim, 1964). Samples coll. 1966 by J. R. Specht, A.N.U.; subm. by Anthropology.

Complex situation involves possibly interconnected factors: burial of site by volcanic ash rapidly redistributed after ashfall, derangement of local drainage, coastal progradation, and transformation of coast locally from muddy embayment to open beach. Different aspects of situation registered in stratigraphy of 11 excavated trenches (9 at Site 6 near present church, 2 at Site $8,50 \mathrm{~m}$ away near present cemetery).

\section{ANU-37b. Site 8, Trench 1,150 to $180 \mathrm{~cm}$ below surface}

Bone from at least 3 burials in discolored sand above white sterile coral beach sand. Sand, 20 to $25 \mathrm{~cm}$ thick, containing shells and Lapita sherds, overlain by 20 to $35 \mathrm{~cm}$ thick black-to-brown clayey loam, containing sherds, representing period of stabilization and overlain by 70 to $80 \mathrm{~cm}$ volcanic ash. Age based on acid-insoluble bone fraction, benzene dilution, 1-day count. ANU-37a, bone carbonate, benzene dilution, 1-day count, dated $910 \pm 110$ (A.D. 1040). Comment (J.R.S.): on grounds of ceramic style Lapita occupation of Watom expected to predate settlement of S Melanesia, where, however, Fiji produces earlier and Tonga equally early dates (cf. ANU-24, ANU I). Sample may not date earliest occupation of site. 


\section{ANU-72. Site 6, Trench VII, ca. $180 \mathrm{~cm}$} below surface

Charcoal from hearth or oven dug into top of redistributed volcanic ash and sealed by narrow zone of silts overlain by thick light brown material (possibly also ash). No associated pottery. Benzene, 1-day count. Comment (J.R.S.): since ash redistribution apparently rapid, should provide close terminus ante quem for ash fall, as well as date post-ash occupation apparently unaccompanied by pottery.

\section{ANU-73. Site 6, Trench VII, $310 \mathrm{~cm}$} below surface

$$
1595 \pm 60
$$

A.D. 345

Waterlogged root or stem wood, probably Alstonia spathulata, growing in situ in clay ca. $70 \mathrm{~cm}$ thick at base of trench. Sample from bottom, ca. $50 \mathrm{~cm}$ below ground water level. Clay contains shells, Lapitastyle potsherds, stone artifacts, and bone. Separated from overlying ash of ANU-72 by banded gritty ash containing sherds. Benzene, 1-day count. Comment (J.R.S.): lack of knowledge about clay formation and associated material prevents archaeological discussion of sample, which dates vegetational phase and approx. age of formation from which it was collected.

\section{ANU-74. Site 6, Trench V, ca. $250 \mathrm{~cm}$ below surface}

$780 \pm 100$

\section{A.D. 1170}

Soil and charcoal at ground water level towards top of clayey soil containing shell and Lapita pottery with pumice pellets in upper part. Clayey soil at base of trench and considered equivalent to clay of ANU73. Trenches are $10 \mathrm{~m}$ apart and stratigraphically different. Trench V, seaward of VII, has no layer of redistributed ash or underlying banded gritty ash in situ and much crab disturbance. Sample from beneath level of redistributed ash of Trench VII. Benzene dilution, 1-day count. Comment (J.R.S.): absence of clearly defined ash and sand layers, though pumice present, may reflect crab disturbance and explain closeness of result to ANU-72. Alternatively date may indicate, with ANU-73, period of basal clay formation, whatever relationship of included archaeological material may prove to be.

\section{ANU-75. Site 6, Trench III, ca. $250 \mathrm{~cm}$ below surface}

$315 \pm 53$

\section{A.D. 1635}

Shells of Canarium (food) nuts from silty clay at base of trench, containing Lapita pottery and shells, just below pumice layer. No in situ layer of redistributed ash; evidence of old stream courses subsequently infilled. Benzene, 1-day count. Comment (J.R.S.): pumice layer slopes steeply; sample may have been deposited on surface but later sunk through it. Tentatively dates start of last phase of aggradation in old 
stream course or embayment. Associated archaeological material is almost certainly not in primary position.

General Comment (J.R.S.): formation of deposits at Site 6 are being investigated; interpretations for individual dates are provisional. ANU$37 \mathrm{~b}$ provides only direct date for Lapita pottery on Watom.

\section{Pacific Islands}

\section{ANU.23/2. Site Tonga 5, near Veitongo village, Tongatapu, Tonga \\ A.D. 1610}

$340 \pm 63$

Charcoal from Fire Hollow D on site $\left(21^{\circ} 11^{\prime} \mathrm{S}\right.$ Lat, $175^{\circ} 13^{\prime} \mathrm{E}$ Long). Repeat of ANU-23 at collector's request, since date critical for interpretation of Tongan ceramic sequence. ANU-23 reported as 330 \pm 100 , physical measurement \pm 80 (ANU I). Coll. 1964 by J. I. Poulsen, A.N.U.; subm. by Anthropology. Benzene, 3-day count. Comment (J.I.P.): confirmation of late date expected on archaeological evidence.

\section{Naïa Bay series, New Caledonia}

Two major excavated sites, $400 \mathrm{~m}$ apart, on W coast ca. $25 \mathrm{~km} \mathrm{NW}$ of Noumea $\left(22^{\circ} 10^{\prime} \mathrm{S}\right.$ Lat, $166^{\circ} 15^{\prime} \mathrm{E}$ Long) provide pottery sequence in which major elements established by Gifford and Shutler (1956) are represented. Samples coll. 1966 by C. D. Smart, A.N.U.; subm. by Anthropology.

\section{ANU.96. TON-7, oven ca. $90 \mathrm{~cm}$ deep}

$3165 \pm 120$

Solid charcoal mass from thick deposit across base of large oven, Layer III, overlying white coral sand. Fill of oven contains few sherds, some with applied, some with stamp-impressed (Lapita-style) decoration. Benzene, 1-day count.

\section{ANU-97. TON-7, oven ca. $50 \mathrm{~cm}$ deep}

Charcoal from one of small ovens associated with lines of postholes within and under Layer IV, which contains paddle-impressed pottery. Benzene, 1-day count.

\section{ANU-98. TON-6, ca. $90 \mathrm{~cm}$ deep}

$1745 \pm 115$

Charcoal from localized area in Layer II, deepest in sequence of 11 horizons, containing pottery with handles. Benzene dilution, 2-day count.

\section{ANU-99. TON-6, 25 to $30 \mathrm{~cm}$ deep}

$1635 \pm 110$

Charcoal from oven sealed by Layer VII, associated with pottery with handles and incised decoration. Benzene, 1-day count.

General Comment (C.D.S.): results agree with those of Gifford and Shutler (1956, p. 89) who reported M-341, $2800 \pm 350$ (before 1954, 846 B.c.) and M-336, $2435 \pm 400$ (before 1954, 481 B.c.) for Lapita ware 
(cf. ANU-96) and M-333, $1700 \pm 300$ (before 1954, A.D. 254) for paddledecorated ware (cf. ANU-97), and series of later dates for poorly understood handled and incised wares (see Michigan I for 1st publication of these dates). Problem of almost identical dates ANU-98 and 99 is under investigation.

\section{New Zealand}

\section{ANU-46b. Kauri Point, western Bay of Plenty, North Island \\ $395 \pm 53$}

Charcoal from 2nd of series of shell lenses laid down following construction of 1 st defenses at fortified settlement $\left(37^{\circ} 30^{\prime} \mathrm{S}\right.$ Lat, $175^{\circ}$ 58' E Long) described in ANU I. Coll. 1962 by W. R. Ambrose, A.N.U.; subm. by Anthropology. Age based on $\mathrm{NaOH}$-insoluble fraction, benzene, 2-day count. ANU-46a, NaOH-soluble fraction, commonly called "humic" and generally thought contaminant, gave $\delta^{14} \mathrm{C}=+47 \pm 5 \%$, benzene dilution, 1-day count, showing it to be more active than ${ }^{14} \mathrm{C}$ Modern reference standard. Comment (W.R.A.): with ANU-25, $495 \pm$ 100 (A.D. 1455), (ANU I), date brackets construction of first defenses at site. Comment (H.A.P.): $\delta^{14} \mathrm{C}$ is observed deviation from standard (Editorial Statement, Radiocarbon, 1966, v. 8).

\section{Waitaki Gorge series, South Canterbury, South Island}

During 1958 to 1960 and 1962, supported by grant from New Zealand Nat. Historic Places Trust, W. R. Ambrose, A.N.U., then of Univ. of Auckland, with Janet Ambrose and F. W. Davis, made records of rock paintings subsequently submerged by Benmore Hydroelectricity Scheme dam (Ambrose et al., 1958-1960). Sites are $60 \mathrm{mi}$ from sea, where Waitaki and tributary gorges afford most direct routes to interior. Excavations made at 3 decorated shelters and samples coll. in hope that, despite lack of direct association of rock art and very thin archaeological occupation, possible order of magnitude for age of art might be given. Only other evidence for this age is conflicting dates from Te Anau, W Otago (Duff, 1956, p. XII), NZ-51, $230 \pm 60$ (A.D. 1720) and NZ-52, $830 \pm$ 50 (A.D. 1120), corrected dates, (New Zealand I-V).

\section{ANU-47. Ahuriri rockshelter, Ahuriri Gorge A.D. 1325}

$625+65$

Charcoal from undisturbed fireplace 6 in. below surface, $\left(44^{\circ} 32^{\prime}\right.$ S Lat, $170^{\circ}$ 12' E Long). Coll. 1958 by W. R. Ambrose; subm. by Anthropology. Benzene dilution, 2-day count.

\section{ANU.48. Gooseneck Bend rockshelter,} Waitaki Gorge

$850 \pm 150$

A.D. 1100

Charcoal and charred twigs from lowest cultural deposit, 6 in. below surface, associated with flake tools, (44 $29^{\prime} \mathrm{S}$ Lat, $170^{\circ} 12^{\prime} \mathrm{E}$ Long). By evidence of superimposition drawings made here over period of time. 
Coll. 1959 by W. R. Ambrose; subm. by Anthropology. Benzene dilution, 1.5-day count.

ANU-49. Junction Point rockshelter, Ahuriri River

Charcoal 6 in. from surface in lowest deposit, $\left(44^{\circ} 33^{\prime} \mathrm{S}\right.$ Lat, $170^{\circ}$ $14^{\prime}$ E Long), associated with flake tools and necklace section of fossil Dentalium, considered early type in New Zealand. Coll. 1962 by W. R. Ambrose; subm. by Anthropology. Benzene dilution, 2-day count. General Comment (W.R.A.): dates early penetration to inland areas of South Island; may be compared with those of inland moa-hunting site of Hawksburn, Central Otago (Lockerbie, 1959, p. 85-87), dated 14th to 16 th century, (NZ-59 to 62 , New Zealand I-V). Thin occupation at shelters suggests equally early art.

\section{REFERENCES}

Date lists:

$\begin{array}{ll}\text { ANU I } & \text { Polach, Stipp, Golson, and Lovering, 1967 } \\ \text { Gakushuin V } & \text { Kigoshi and Kobayashi, 1966 } \\ \text { Gakushuin VI } & \text { Kigoshi, 1967 } \\ \text { Geochron I } & \text { Krueger and Weeks, 1965 } \\ \text { Michigan I } & \text { Crane, 1956 } \\ \text { New Zealand I-V } & \text { Grant-Taylor and Rafter, 1963 } \\ \text { NPL III } & \text { Callow, Baker, and Hassall, 1965 } \\ \text { USGS VI } & \text { Rubin and Berthold, 1961 } \\ \text { Yale VIII } & \text { Stuiver, Deevey, and Rouse Jr., 1963 }\end{array}$

Allen, James, 1967, The technology of colonial expansion: a nineteenth century military outpost on the north coast of Australia: Industrial Archaeol, v. 4, p. 111-137. Ambrose, W. and Davis, F., 1958, Interim report on the recording of Maori rock shelter art at Benmore: Report of the Nat. Hist. Places Trust for the year ended 31 March 1958, app. I, p. 11-24.

1960 , Final report on the recording of Maori rock shelter art at Benmore: Report of the Nat. Hist. Places Trust for the year ended 31 March 1960, app. III, p. 14-16.

Ambrose, W., Ambrose, J., and Davis, F., 1959, Further report on the recording of Maori rock shelter art at Benmore: Report of the Nat. Hist. Places Trust for the year ended 31 March 1959, app. II, p. 19-24.

Anderson, E. C. and Levi, H., 1952, Some problems in radiocarbon dating: Dan. Mat. Fys. Medd., v. $27(6)$.

Berger, R., Horney, A. G., and Libby, W. F., 1964, Radiocarbon dating of bone and shell from their organic components: Science, v. 144, p. 999-1001.

Bowler, J. M. and Harford, L. B., 1966, Quaternary tectonics and the evolution of the Riverine plain near Echuca, Victoria: Geol. Soc. Australia Jour., v. 13, p. 339-354.

Bowler, J. M., Mulvaney, D. J., Casey, D. A., and Darragh, T. A., 1967, Green Gully burial; Nature, v. 213, p. 152-154.

Bulmer, S., 1966, The antiquity of pigs in the New Guinea Highlands: Polynesian Soc. Jour., v, 75, p. 504-505.

Butler, B. E., 1959, Periodic phenomena in landscapes as a basis for soil studies: Canberra, Commonwealth Sci. and Ind. Res. Org., Aust. Soil Publ., no. 14.

Callow, W. I., Baker, M. J., and Hassall, G. I., 1965, National Physical Laboratory radiocarbon measurements III: Radiocarbon, v. 7, p. 156-161.

Casey, D. A., 1936, Ethnological notes: Memoirs of the Nat. Mus. of Victoria, v. 9, p. $90-97$.

Crane, H. R., 1956, University of Michigan radiocarbon dates I: Science, v. 124, p. 664-672.

Duff, R. S., 1956, The Moahunter period of Maori culture (2nd ed.): Wellington, Government Printer. 
Gifford, E. W. and Shutler, D., Jr., 1956, Archaeological excavations in New Caledonia: Berkeley and Los Angeles, Univ. of California Press, Anthrop. Rec., v. 18(1).

Gill, E. D., 1966, Provenance and age of Keilor cranium: Current Anthropology, v. 7 , p. $581-584$.

Golson, Jack, 1961, Report on New Zealand, Western Polynesia, New Caledonia and Fiji: Asian Perspectives, v. 5, p. 166-180.

Golson, Jack, Lampert, R. J., Wheeler, J. M., and Ambrose, W. R., 1967, A note on carbon dates for horticulture in the New Guinea Highlands: Polynesian Soc. Jour., v. 76, in press.

Grant-Taylor, T. L. and Rafter, T. A., 1963, New Zealand natural radiocarbon measurements I-V: Radiocarbon v. 5, p. 118-162.

Kigoshi, Kunihiko, 1967, Gakushuin natural radiocarbon measurements VI: Radiocarbon, v. 9, p. 43-62.

Kigoshi, Kunihiko and Kobayashi, Hiromi, 1966, Gakushuin natural radiocarbon measurements V: Radiocarbon, v. 8, p. 54-73.

Krueger, H. W., 1966, The preservation and dating of collagen in ancient bones: in Proceedings of 6th Internatl. Conf. Radiocarbon and Tritium dating, 1965, Pullman, Washington, p. 332-337.

Krueger, H. W. and Weeks, C. F., 1965, Geochron Laboratories, Inc. radiocarbon measurements I: Radiocarbon, v. 7, p. 47-53.

Lampert, R. J., 1967, Horticulture in the New Guinea Highlands: carbon dates from a recent excavation: Antiquity, v. 41, p. 307-309.

Libby, W. F., 1963, Accuracy of radiocarbon dates: Science, v. 140, p. 278-280.

Lockerbie, L., 1959, From Moa-hunter to Classic Maori in southern New Zealand: in Anthropology in the South Seas, ed. by J. D. Freeman and W. R. Geddes, New Plymouth, Avery, p. 75-110.

McBryde, Isabel, 1962, Archaeological field survey work in northern New South Wales: Oceania, v. 33 , p. $12-17$.

Meyer, P. O., 1909, Funde prähistorischer Töpferei und Steinmesser auf Vatom, Bismarck Archipel: Anthropos, v. 4, p. 251-252, 1093-1095.

Olson, E. A., 1963, The problems of sample contamination in radiocarbon dating: Ph.D. thesis, Columbia Univ., unpubl.

Pels, Simon, 1966, Late Quaternary chronology of Riverine plain of southeastern Australia: Geol. Soc. Australia Jour., v. 13, p. 27-40.

Polach, H. A. and Golson, J., 1966, Collection of specimens for radiocarbon dating and interpretation of results: Canberra, Australian Inst. of Aboriginal Studies, manual no. 2.

Polach, H. A. and Stipp, J. J., 1967, Improved synthesis technique for methane and benzene radiocarbon dating: Internatl. Jour. Appl. Radiation and Isotopes, v. 18 , p. $359-364$.

Polach, H. A., Stipp, J. J., Golson, J., and Lovering, J. F., 1967, ANU radiocarbon date list I: Radiocarbon, v. 9, p. 15-27.

Poulsen, Jens, 1964, A preliminary report on pottery finds in Tonga: Asian Perspectives, v. 8 , p. 184-195.

Rubin, Meyer, and Berthold, S. M., 1961, U. S. Geological Survey radiocarbon dates VI: Radiocarbon, v. 3, p. 86-98.

Solheim, W. G., II, 1964, Further relationships of the Sa-huynh-Kalanay pottery tradition: Asian Perspectives, v. 8, p. 196-211.

Stuiver, Minze, 1967, Origin and extent of atmospheric C-14 variations during the past 10,000 years: in Radioactive dating and methods of low level counting, Proc. Monaco Conf. March 1967, p. 27-40.

Stuiver, Minze, Deevey, E. S., Jr., and Rouse, I., 1963, Yale natural radiocarbon measurements VIII: Radiocarbon, v. 5, p. 312-341.

Stuiver, Minze and Suess, H. E., 1966, On the relationship between radiocarbon dates and the true sample ages: Radiocarbon, v. 8, p. 534-540.

Suess, H. E., 1967, Bristlecone pine calibration of the radiocarbon time scale from 4100 B.c. to 1500 B.c.: in Radioactive dating and methods of low-level counting, Proc. Monaco Conf. March 1967, p. 143-151.

Tamers, M. A. and Pearson, F. J., Jr., 1965, Validity of radiocarbon dates on bone: Nature, v. 208, p. 1053-1055.

Tauber, Henrik, 1958, Difficulties in the application of C-14 results in archaeology: Archaeologia Austriaca, v. 24, p. 59-69. 
Walker, P. H., 1962, Terrace chronology and soil formation on the south coast of N.S.W.: Jour. Soil Sci., v. 13, p. 178-186.

White, Carmel, 1967, Early stone axes in Arnhem Land: Antiquity, v. 41, p. 149-152. White, J. P., 1965, An archaeological survey in Papua-New Guinea: Current Anthropology, v. 6, p. 334-335.

1965, Archaeological excavation in New Guinea: an interim report: Polynesian Soc. Jour., v. 74, p. 40-56.

1967, Taim bilong bipo: investigations towards a prehistory of
New Guinea Highlands: Ph.D. thesis, Australian Natl. Univ., unpubl. 